\title{
OD NÁSTROJOV A ZBRANÍ K SYMBOLOM: ANALÝZA PRACOVNÝCH STÔP NA KOVOVÝCH DÝKACH STARŠEJ DOBY BRONZOVEJ V ČECHÁCH
}

\author{
Pilotná štúdia ${ }^{1}$
}

\author{
K A T A RÍNA PETRI ŠČÁKOVÁ - M A REK V ERČÍK - \\ PETER PAVÚK - PETR LIMBURSKÝ - DAVID DA N ĚČEK - \\ M I C H A L E R N É E
}

\begin{abstract}
From Tools and Weapons to Symbols: Use-wear Analysis of the Early Bronze Age Metal Daggers in Bohemia. Pilot Study. In our lands, the Early Bronze Age is commonly associated with the occurrence of daggers in graves. However, the majority of research linked with the publication or further analysis of the local dagger finds usually highlighted just their occurrence (or not) in the graves per se, followed by a discussion of their chronology and typology. The function of the daggers and their role in a social context have not been tackled that much so far. Abroad, on the contrary, a whole methodology for the study of use-wear traces on bronze artefacts has been developed in the meantime. And while it has been applied to typologically different specimens, mainly artefacts linked to warfare, we are equally convinced of its applicability to daggers deposited in the graves of the Únětice culture. This pilot study therefore targets traces of their specific use, the influence of post-depositional processes, and the interpretation of organic residues. The preliminary results highlight the applicability of such an approach to the daggers as well and indicate their potential for the reconstruction of the 'life cycle of the artefacts'.
\end{abstract}

Keywords: Bohemia, Early Bronze Age, graves, daggers, use-wear analysis.

Pri príležitosti významného jubilea prof. J. Bátoru by sme radi predložili v našom priestore dosial' nepublikovanú štúdiu funkčnej analýzy kovových dýk únětickej kultúry z oblasti stredných Čiech. Týmto skromným pilotným projektom by sme radi nadviazali na významné celoživotné dielo nášho jubilanta, ktoré je úzko späté nielen so staršou dobou bronzovou na Slovensku, ale aj v celoeurópskom priestore.

\section{ÚVOD}

Únětická kultúra staršej doby bronzovej je na našom území spojená $s$ výskytom kovových dýk v pohrebnom kontexte. Do dnešnej doby sa domáce bádanie prevažne uchylovalo len k obecnému konštatovaniu prítomnosti dýk $\mathrm{v}$ hrobovej výbave, väčšinou vo vztahu $\mathrm{k}$ (prevažne mužskému) pohlaviu (Dobisíková/Hložek/Menšík 2018; Ernée ed. 2015; Jiráň ed. 2008; Limburský a kol. 2018; Moucha 1954; Petriščáková 2014; Smejtek 2005; Šulová 2013 a pod.). Iné štúdie sa zase sústredovali na typológiu a chronológiu dýk (Bartelheim 1998; Novák 2011). Otázka funkcie dýk tak bola dlhú dobu pomerne opomínaná. Prevládal názor, že pre svoje pomerne malé rozmery a krehkú štruktúru predstavujú skôr symboly než reálne nástroje alebo zbrane (Neustupný 1997).

V zahraničí sa primárna pozornosṫ funkčnej analýzy sústredila prevažne na pozorovanie pracovných stôp na čepeliach piatich kovových typov artefaktov doby bronzovej spojených s fenoménom vojenstva meče, štíty, Stabdolchy, sekery a oštepy - a identifikáciu bojových techník (napr. Bunnefeld/Schwenzer 2011; Dolfini/Crellin 2016; Dolfini a i. 2018; Gutiérrez-Sáez/ Martín-Lerma 2015; Horn 2013a; 2013b; 2017; 2018; Horn/ von Holstein 2017; Kristiansen 2002; Melheim/Horn 2014; Molloy 2008; 2011; 2017; Mödlinger 2011; O'Flaherty/ Gilchrist/Cowie 2011; Uckelmann 2011 a pod.).

Jedno z prvých makroskopických pozorovaní dýk staršej doby bronzovej v hrobových nálezoch v južnom Anglicku previedla J. Wall (1987). Jej závery vychádzajú z interpretácie vol'ným okom viditel'ných stôp bez vypracovania a zohladnenia akýchkolvek metodických postupov. Prostredníctvom dokladov pracovných stôp sa pokúsila riešit tri základné otázky, ktoré sa vztahovali na vzhlad, funkciu a distribúciu artefaktov. V priebehu niekol'kých d’alších rokov sa interpretácie funkcie dýk pohybo-

\footnotetext{
1 M. Ernée bol podporený cenou Praemium Academiae AV ČR, P. Limburský inštitucionálnym programom RVO 67985912, P. Pavúk a M. Verćík univerzitným programom PROGRES Q09.
} 
vali skôr v teoretickej rovine bez experimentálnych pozorovaní (Keates 2002; Weinberger 2008). A. Dolfini (2011) analyzoval dýky so stredovým rebrom z oblasti Talianska. Okrem výrobných stôp a prvkového zloženia kovu sa pokúsil identifikovat i pracovné stopy na čepeliach. Vyjmúc dodatočné povýrobné úpravy, inak prekvapivo neregistroval žiadne stopy použivania. V dôsledku týchto záverov sa priklonil k interpretácii, že dýky boli asi skôr využívané ako nástroje primárne určené $\mathrm{k}$ rituálnemu zabíjaniu zvery a krájaniu mäsa (cf. Skak-Nielsen 2009). Tieto aktivity nezanechávajú na čepeliach významné zmeny, a preto často nie sú identifikovatelné. Zároveň nevylučoval, že by dýky mohli slúžit i ako zbrane a lahko spôsobit poranenie ludských svalov a tkanív s následkom smrti (Dolfini 2011). Záslužné dielo z britského prostredia publikovali S. Needham a P. Bray (2015). Analyzovali sedem typov kovových dýk a nožov z neskorého eneolitu a staršej doby bronzovej. Na väčšine z nich identifikovali stopy výroby a použitia. $V$ jednej z posledných štúdií venovanej tejto problematike sa autori L. Perucchetti, J. P. Northover a M. David-Elbiali (2020) venovali metalurgickej interpretácii troch dýk z neskorého eneolitu a včasnej doby bronzovej z oblasti západného Švajčiarska. Na základe výsledkov prevedenej analýzy, ktorá nepreukázala stopy po bodaní, definovali dýky ako pravdepodobne multifunkčné (rezacie) nástroje.
Analýzy pracovných stôp na kovových dýkach a ostatných typoch artefaktov prevedené $\mathrm{v}$ zahraničí poukazujú na vel'ký potenciál využitia sformovaných metodických prístupov na našom materiáli (cf. Petriščáková 2019). Definícia funkcie artefaktov je úzko spojená s otázkou ich použitia $\mathrm{v}$ bežnom živote. $\mathrm{V}$ riešenej problematike možno badat niekol'ko oblastí záujmu, ktoré sú navzájom prepojené bez možnosti ich úplnej separácie. Je nutné oboznámit sa so sociálnou hodnotou artefaktu, jeho úlohou v ekonomike a technologickým procesom. Zároveň je potreba vziat' v úvahu okolnosti týkajúce sa samotného artefaktu: zloženie suroviny, produkciu, spotrebu/použitie, recykláciu, deponovanie a opätovné vyzdvihnutie, uloženie a ošetrenie (Dolfini 2011). Jedným z prejavov hmotnej kultúry v staršej dobe bronzovej je používanie pre toto obdobie charakteristických dýk v pohrebnom ríte. Základným problémom je identifikácia týchto artefaktov v sociálnom kontexte, kedže odraz pôvodnej živej kultúry dokážeme zachytit už len ako výsledok rôznych postdepozičných procesov.

\section{METODIKA}

Pre potreby na tomto mieste prezentovanej analýzy pracovných stôp bol použitý súbor 15 kovových

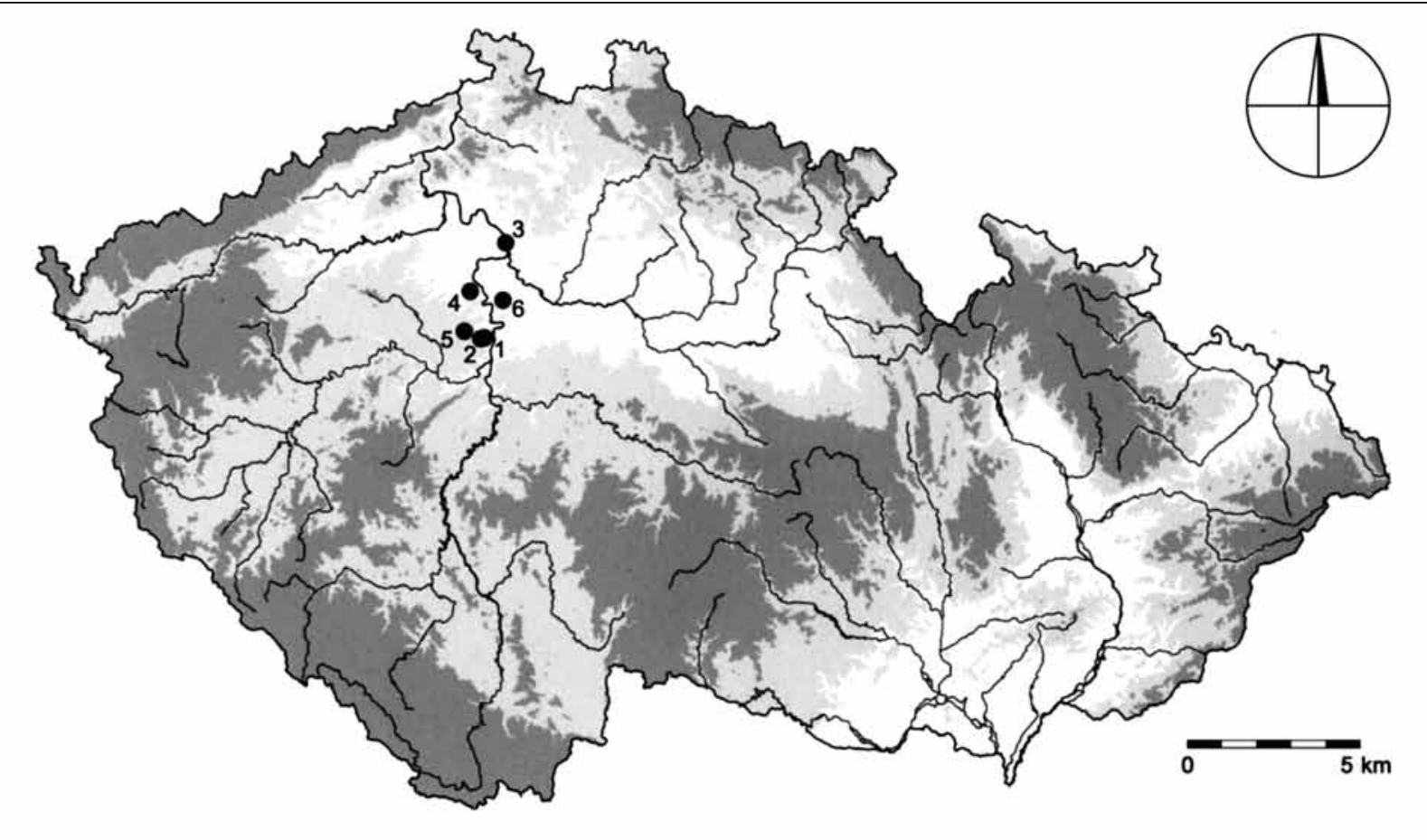

Obr. 1. Lokalizácia pohrebísk staršej doby bronzovej s dýkami v Čechách. 1 - Praha-Jinonice; 2 - Praha-Stodůlky; 3 Vliněves, okr. Mělník; 4 - Holubice, okr. Praha-západ; 5 - Hostivice, okr. Praha-západ; 6 - Klecany, okr. Praha-východ (grafická úprava M. Kafka). 
Tabela 1. Dýky z pohrebísk staršej doby bronzovej v Čechách. Základná charakteristika materiálu a nálezový kontext. Skratky: MMP - Muzeum hlavního města Prahy; ARÚP - Archeologický ústav, AV ČR, Praha, v.v.i.; SMR - Středočeské muzeum v Roztokách u Prahy.

\begin{tabular}{|c|c|c|c|c|c|c|}
\hline $\begin{array}{l}\text { Identifikačné } \\
\text { číslo }\end{array}$ & $\begin{array}{l}\text { Zachovaná } \\
\text { d́žka (mm) }\end{array}$ & Datovanie & Lokalita & Hrob č. & Inštitúcia & Literatúra \\
\hline A 254931 & 83 & BA1 & Praha-Jinonice & 30 & MMP & Petriščáková 2009; 2011 \\
\hline A 360187 & 61 & BA2 & Praha-Stodůlky & 36 & MMP & Petriščáková 2009; 2011 \\
\hline A 360215 & 115 & BA2 & Praha-Stodůlky & 40 & MMP & Petriščáková 2009; 2011 \\
\hline A 360318 & 68 & BA2 & Praha-Stodůlky & 50 & MMP & Petriščáková 2009; 2011 \\
\hline A 360321 & 125 & BA2 & Praha-Stodůlky & 51 & MMP & Petriščáková 2009; 2011 \\
\hline A 360326 & 63 & BA2 & Praha-Stodůlky & 54 & MMP & Petriščáková 2009; 2011 \\
\hline A 519326 & 110 & BA2 & Praha-Stodůlky & 21 & MMP & Petriščáková 2014 \\
\hline V 1047 & 68 & BA2 & Vliněves, Mělník & 67 & ARÚP & Limburský a kol. 2018 \\
\hline V 4440 & 109 & BA2 & Vliněves, Mělník & 475 & ARÚP & Limburský a kol. 2018 \\
\hline V 5710 & 154 & BA2 & Vliněves, Mělník & 533 & ARÚP & Limburský a kol. 2018 \\
\hline V 8099 & 108 & BA2 & Vliněves, Mělník & 424 & ARÚP & Limburský a kol. 2018 \\
\hline SMR 3 & 51 & BA2 & Holubice, Praha-západ & 3 & SMR & Daněček/Klementová 2014 \\
\hline SMR 26 & 83 & BA2 & Holubice, Praha-západ & 26 & SMR & Daněček/Kvěchová/Vávrová 2015 \\
\hline SMR 2506 & 121 & BA2 & Hostivice, Praha-západ & 2506 & SMR & Jiráň ed. 2013; Daněček 2016 \\
\hline K 67 & 144 & BA2 & Klecany, Praha-východ & 67 & ARÚP & Ernée/Profantová a i. 2011 \\
\hline
\end{tabular}

artefaktov zo šiestich pohrebísk únětickej kultúry v stredných Čechách (obr. 1). Typologicky tieto artefakty môžeme definovat ako trojuholníkové čepele s takmer rovným, oblým až strechovitým tylom. Dochovaná dľžka čepelí a počet otvorov pre nity sa značne líšia (Ernée/Profantová a i. 2011; Petriščáková 2019). Všetky examinované čepele boli uložené v kostrových hroboch (tabela 1). Samotný priebeh funkčnej analýzy bol zameraný na stopy použitia, postdepozičné procesy a rezíduá.

Makroskopické stopy sú volným okom viditelné fyzické deformácie zamerané na asymetriu a ulomené časti artefaktov. $\mathrm{K}$ najčastejším prejavom patria deformácia profilu, kedy dochádza k ohnutiu hornej alebo dolnej časti profilu. Deformácia dolnej časti čepele, ktorá je vychýlená oproti pôvodnému tvaru, najčastejšie vzniká silným tlakom alebo silným nárazom na tvrdý povrch. Pri totálnej deformácii torza dochádza $\mathrm{k}$ pozdížnemu prehnutiu dýky až do momentu, kedy jedna dlhšia strana prekrýva druhú dlhšiu stranu (Gutiérrez-Sáez/Martín-Lerma 2015). Odlomenie špičiek čepelí alebo rozlomenie artefaktu môže byt' spôsobené nárazom predmetu do tvrdšej substancie alebo namáhaním materiálu (Kristiansen 2002). Zaoblenie hrán čepelí vzniká v dôsledku otupenia pri rezaní hlavne mäkkého materiálu (Gutiérrez-Sáez/Martín-Lerma 2015).Zlomeniny a praskliny na rôznych miestach artefaktu sú spojované s používaním artefaktu, ale aj s postdepozičnými procesmi (Gutiérrez-Sáez/Martín-Lerma 2015).

Plastické deformácie boli pozorované mikroskopicky. Tieto stopy indikujú únavu materiálu a schopnost' deformácie proti použitej sile bez schopnosti návratu do pôvodného stavu. Podla tvaru deformácií a spôsobu vzniku rozoznávame niekol'ko základných typov pracovných stôp (podla Dolfini 2011; Gutiérrez-Sáez/Martín-Lerma 2015; Molloy 2011):

Zásek -je sečná stopa na čepeli. Má tvar písmena $\mathrm{V}$ a ostrý profil naznačuje odraz čepele od tvrdého materiálu, pravdepodobne d’alšiu čepel'. Väčšinou ide o jednorazový zásah, kedy kov na hrane čepele nie je odstránený, ale stlačený alebo vychýlený na jednu alebo druhú stranu. Môže byt sprevádzaný prasklinou.

Zárez - je rezná stopa na čepeli. Má tvar písmena U. Pri náraze na čepel’ dochádza k odštiepeniu alebo ulomeniu kusu kovu z pôvodnej pozície, a tak vzniká medzera na hrane čepele. Je výsledkom rotačného pohybu pri náraze čepele na čepel’ alebo čepele na tvrdší materiál. Sprievodným javom tohto znaku môže byt̉ prasklina alebo lom.

Vlnenie - predstavuje „zvlnenú“ hranu, ktorá vzniká sústavou vedla seba nasledujúcich zárezov. Tento druh deformácie vzniká po náraze sklzom čepele po tvrdšom materiáli alebo po tvrdšej čepeli. Príčinou vzniku môže byt’ aj jednorazové alebo viackrát opakované rezanie a krájanie.

Všetky pracovné stopy sa môžu vyskytovat' na čepeliach dýk v kombinovanej podobe a zároveň $\mathrm{k}$ nim môžeme priradit i všetky postdepozičné zmeny spôsobené dodatočnou manipuláciou a laboratórnym spracovaním (Gutiérrez-Sáez/Martín-Lerma 2015). 

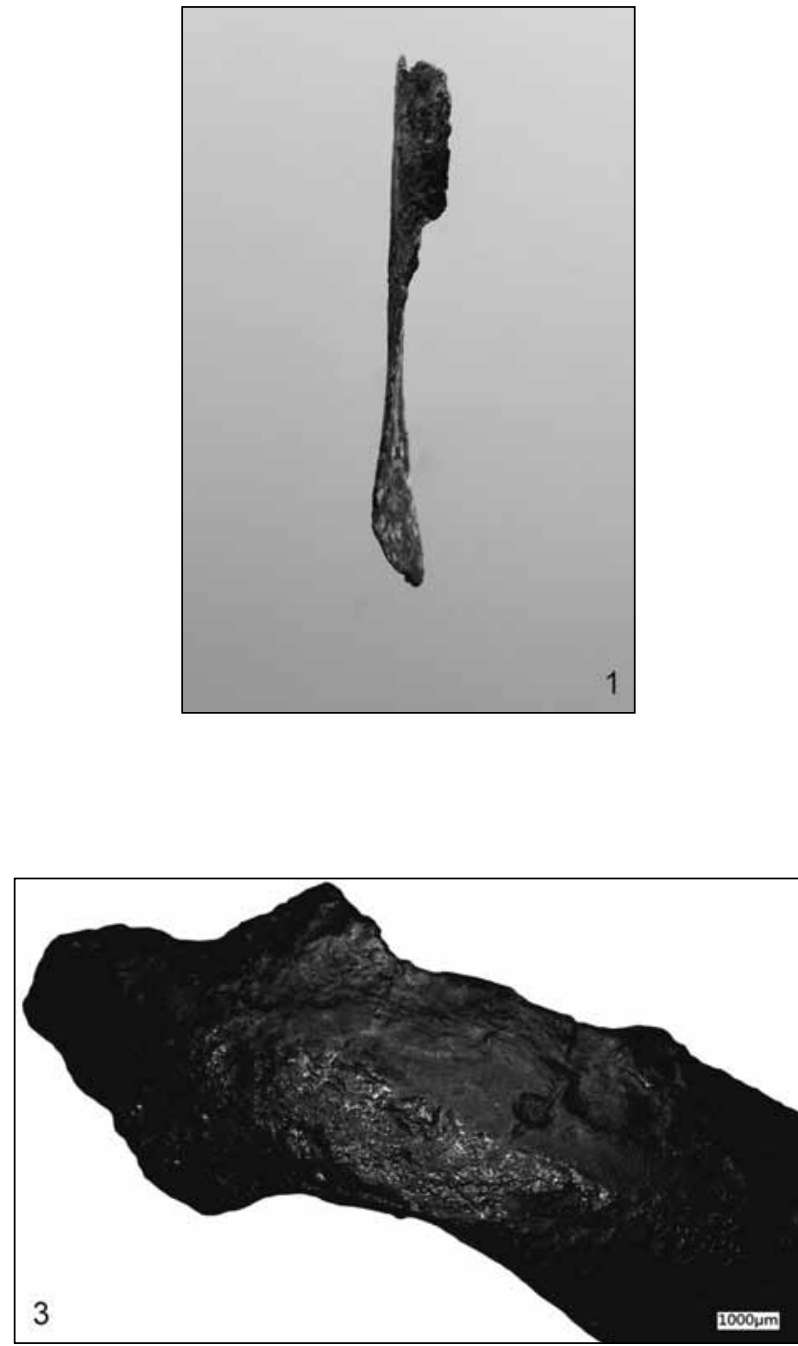

$1000 \mathrm{\mu m}$
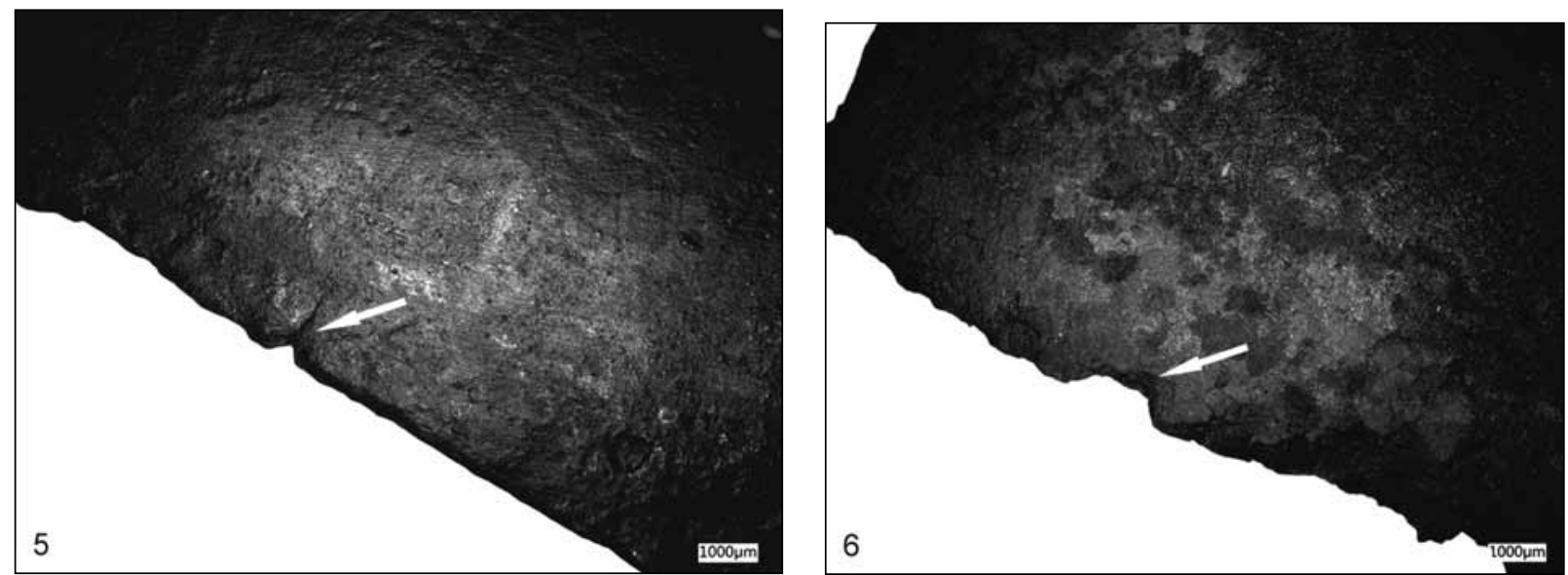

Obr. 2. Pracovné stopy na kovových čepeliach dýk z pohrebísk staršej doby bronzovej v Čechách. 1 - dýka A 360326 , deformácia profilu; 2 - dýka SMR 3, stav pred konzerváciou, odlomená špička pokrytá vápenitou konkréciou, na tyle zrejmé pozostatky dreva; 3 - dýka V 5710, opotrebovaná špička čepele; 4 - dýka 360 215, zásek V (hore) a zaoblenie hrany (dole); 5 - dýka V 8099, zásek V doplnený kolmou prasklinou; 6 - dýka A 360 187, zárez U (mikroskopické snímkovanie K. Petriščáková; grafická úprava M. Kafka). 
Na pozorovanie pracovných stôp má výrazný vplyv i ošetrenie a skladovanie artefaktov po vyňatí z pôvodného kontextu. Mechanické čistenie, chemické ošetrenie a dolepovanie odlomených častí zanecháva na pôvodnom povrchu "falošné" stopy v podobe poškrabania povrchu alebo hrán, zmeny farby artefaktov alebo likvidáciu pôvodných stôp. Rovnako nepriaznivo na pozorovanie pôsobí použitie konzervačných voskov a lakov, ktoré vytvárajú na povrchu nežiadúci lesk a môžu ovplyvnit identifikáciu pracovných stôp (Dolfini 2011). Pre potreby odlíšenia a rozpoznania i menších zlomenín a dolepených častí artefaktu bolo použité RTG snímkovanie všetkých čepelí (Petriščáková 2019).

$\mathrm{Na}$ kovových artefaktoch v prípade vhodných podmienok registrujeme prilepené kúsky organického materiálu, ktoré postupne $\mathrm{v}$ priebehu deponovania boli impregnované oxidmi medi (Ernéel Profantová a i. 2011; Peška/Králík/Selucká 2008). Tieto rezíduá môžeme rozdelit do troch skupín: $\mathrm{v}$ prvom prípade ide o zvyšky adhezív, ktoré slúžili ako spojivá rôznych materiálov (napr. živica, ktorá slúžila ako podporný prostriedok na prichytenie rukoväti k čepeli); dalším prípadom sú pozostatky organických rukovätí alebo puzdier (najčastejšie z dreva alebo látky) zaznamenané na povrchu čepele; v poslednom prípade ide o zostatok kontaktného materiálu (koža, vlasy, zvieracie štetiny a pod.). Neopatrným ošetrením a konzerváciou dochádza k nenávratnej likvidácii tohto typu pozorovaní (Gutiérrez-Sáez/ Martín-Lerma 2015).

Metodický postup pri analýze pracovných stôp na jednotlivých dýkach vznikol komparáciou používaných stanovených postupov na iných typoch artefaktov (meče, hrotité sekery/Stabdolchy, sekery a oštepy). Prístup aplikovaný na dýky prezentované na tomto mieste bolo nutné prispôsobit aktuálnym možnostiam, aby boli dosiahnuté optimálne a použitelné výsledky pozorovania. Pre každú dýku bol vytvorený analytický protokol, ktorý obsahoval základné kategórie morfologických a chemických zmien pozorovaných volným okom i mikroskopicky. Detailná analýza jednotlivých artefaktov bola prevedená digitálnym mikroskopom Keyence VXH-500 FD so snímacou kamerou s rozlíšením 1600 x 1200 px a dvomi menitel'nými objektívmi s osvetlením. Z každej examinovanej dýky boli urobené série fotografických snímok, kedy bol artefakt zaznamenaný po celom svojom obvode spolu s povrchom so zväčšením v rozsahu $11 \mathrm{x}$ až 20x s pracovnou vzdialenostou približne $30 \mathrm{~mm}$. Detegované miesta boli podrobené samostatnému snímkovaniu dalším objektívom s max. rozlíšením 50x až 150x s pracovnou vzdialenostou asi $5-10 \mathrm{~mm}$. Dokumentované stopy boli porovnávané s publi- kovanými snímkami variabilných odtlačkov pracovných stôp, ktoré boli získané experimentálnym spôsobom na replikách artefaktov (Dolfini 2011; Dolfini/Crellin 2016; Gutiérrez-Sáez/Martín-Lerma 2015; Horn/Karck 2019; Horn/von Holstein 2017; Molloy 2011; Soriano-Llopis/Gutierrez-Sáez 2008).

\section{ANALÝZA PRACOVNÝCH STÔP}

\section{Postdepozičné zmeny}

Z celkového počtu 15 dýk bolo celkom 13 dýk laboratórne ošetrených a konzervovaných. Na všetkých mechanicky očistených a konzervovaných artefaktoch sa zachovali „falošné" pracovné stopy, ktoré stažovali identifikáciu "use-wear" markantov. Najčastejším problémom bolo ošetrenie lakom a voskom. Tahy štetca imitovali brúsenie hrán a povrchu artefaktu (obr. 3: 5). Pri mechanickom čistení dochádzalo k poškrabaniu patiny a nemožno vylúčit, že takýmto spôsobom boli odstránené i zvyšky rezíduí (obr. 3: 6). Lepidlo používané na prilepenie odlomených častí prekrývalo zlomeniny, takže boli tažko identifikovatelné (obr. 3: 2). $\mathrm{Z}$ toho dôvodu boli všetky dýčky röntgenované, aby boli odhalené prípadné zamaskované zlomeniny a defekty (obr. 3: 3). Pri chemických zmenách v dôsledku postdepozičných procesov došlo $\mathrm{k}$ zmene farby patiny alebo $\mathrm{k}$ sublimácii kovov na povrchu piatich artefaktov (A 360 318, A 360 321, A 360 326, A 519 263, SMR 26).

Na dvoch nekonzervovaných dýkach (SMR 3, SMR 26) ostali nánosy hliny, ktoré stazžili observáciu. Na druhej strane zase bolo možné odlíšit recentné zárezy vzniknuté $\mathrm{v}$ priebehu exkavácie a manipulácie po vyňatí z hrobového kontextu od pôvodných stôp (obr. 3: 7). Na neošetrených dýkach sa pri rukoväti taktiež objavili pozostatky pôvodného spojiva, pravdepodobne živice (obr. 3: 4).

\section{Pracovné stopy (use-wear)}

Makroskopicky boli pozorované fyzické deformácie a ulomené časti artefaktov. Deformácia profilov artefaktov sa prejavila len v dvoch prípadoch. Ohnutú dolnú čast’ mala jedna čepel' (A 360 215). Mierny stupeň ohnutia bol pravdepodobne spôsobený až po uložení do hrobu v podobe prídavku. Deformáciu mohol spôsobit tlak zeminy alebo hrobového závalu. Profil d'alšej dýky (A 360 326) môžeme klasifikovat’ ako absolútnu deformáciu tela (obr. 3: 1). Pozdížne strany sú $\mathrm{v}$ tomto prípade takmer vychýlené do opačných strán a $\mathrm{v}$ pozícii oproti kratším stranám. Tento stav môže byṫ zapríčinený i vysokým stupňom 

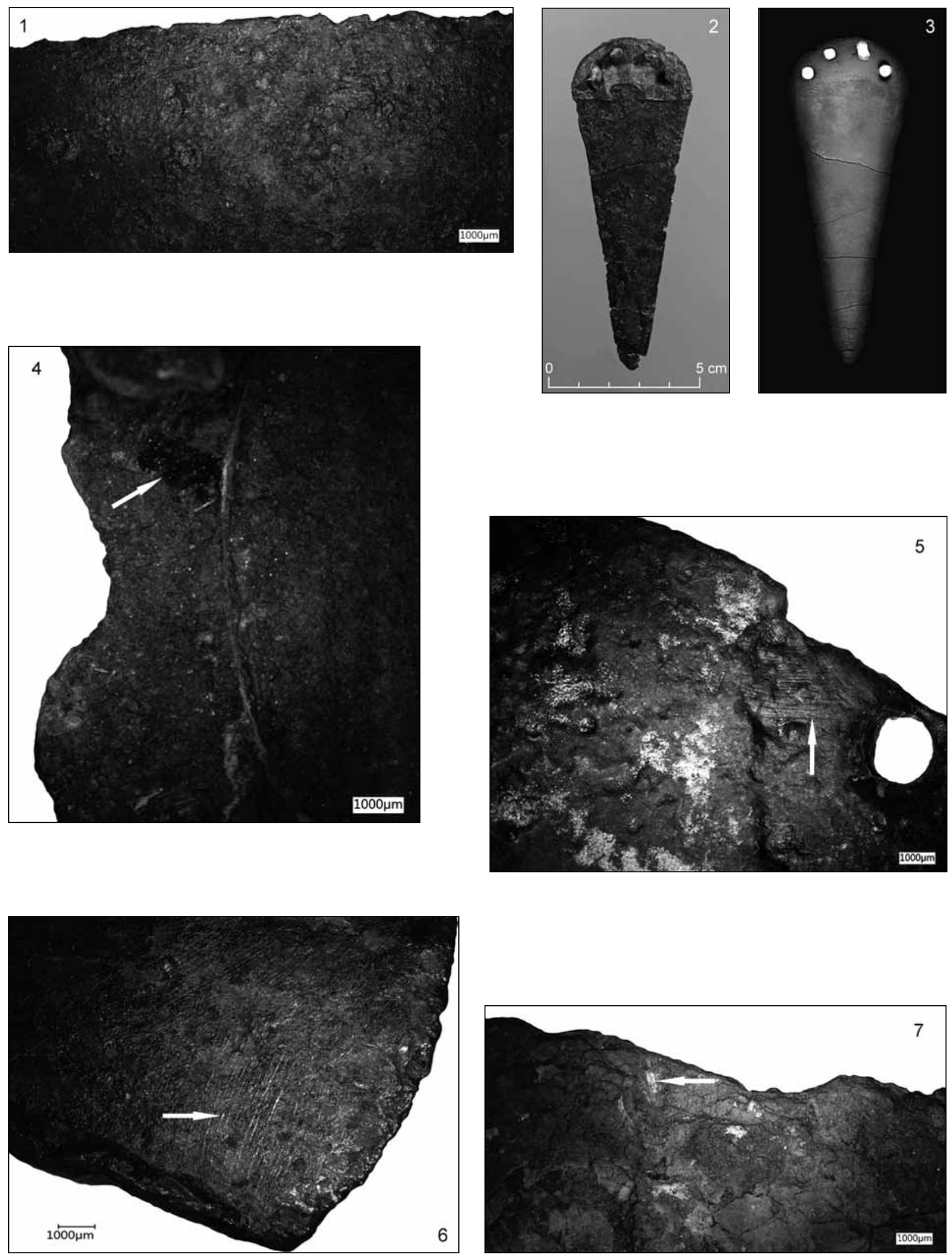

Obr. 3. Pracovné stopy na kovových čepeliach dýk z pohrebísk staršej doby bronzovej v Čechách. 1 - dýka SMR 2506, zvlnenie hrán; 2 - dýka A 360 215, slabo viditelné zlomeniny čepele a pozostatky dreva na tyle; 3 - dýka A 360 215, RTG zlomenín a prasklín čepele; 4 - dýka SMR 26, živica na neskonzervovanom tyle dýky; 5 - dýka V 4400, tahy štetcom po konzervácii; 6 - dýka A 230 102, poškrabaný povrch pri odstraňovaní patiny; 7 - dýka SMR 3, recentný zásek (mikroskopické snímkovanie K. Petriščáková; grafická úprava M. Kafka). 
korózie artefaktu alebo druhotným javom (možno kontaktom s ohňom).

Rovnakým spôsobom boli v desiatich prípadoch identifikované odlomené alebo poškodené špičky dýk. Tieto artefakty sú rozdelené do troch skupín. Štyri dýky (A 360 187, A 360 318, SMR 3, V 8099) boli deponované už v poškodenom (neúplnom) stave. Túto situáciu najlepšie demonštruje dýka SMR 3 (obr. 2: 2), ktorá má špičku obalenú vápenitou konkréciou. Z tohto stavu je zrejmé, že k ulomeniu časti nedošlo pri exkavácii v teréne alebo neskoršou manipuláciou. $\mathrm{V}$ podobnom stave sú ostatné tri dýky, ktoré nie sú obalené kalcitom, ale na základe pokročilej patinácie hrany zlomu možno usudzovat', že nejde o čerstvý lom vzniknutý v postdepozičnom procese. Do druhej skupiny patria tri artefakty (A 360 215, A 360 326, SMR 26), ktorých špička bola po vyzdvihnutí odlomená. Po laboratórnom spracovaní však špičky boli opätovne prilepené k zbytku čepele. Z toho môžeme usudzovat', že dýky vo forme prídavku boli do hrobu pridané takmer $\mathrm{v}$ kompletnom stave, ale $\mathrm{v}$ postdepozičnom procese došlo k polámaniu namáhaného materiálu. Značne opotrebované a čiastočne olámané špičky boli zaregistrované pri troch dýkach (V 5710, SMR 2506, K 67). Tieto znaky potom môžeme považovat' za známku vykonávaných pracovných aktivít.

Zaoblenie hrán čepelí bolo detegované v šiestich prípadoch (A 360215, A 360318 , V 1047, V 4400, V 5710, V 8099). Tento druh pracovných stôp vzniká otupením hrán artefaktu pri krájaní a rezaní, ale nevylučuje sa ani pôsobenie exogénnych faktorov (obr. 2:4).

$\mathrm{K}$ najmarkantnejším identifikátorom funkčnej analýzy patria $(\mathrm{V})$ záseky, $(\mathrm{U})$ zárezy a zvlnenie hrán artefaktu. Jednotlivé alebo opakované záseky na viacerých miestach čepele boli objavené na siedmich čepeliach (A 254 931, A 360 187, A 360 215, A 519263 , V 4400, V 8099, K 67). V niektorých prípadoch boli sprevádzané i prasklinou, ktorá vznikla pri razantnom údere na ostrú hranu predmetu (obr. 2: 5).

Zárezy, ktoré predstavujú „,vyšklbnutie“ materiálu a vznik medzery na inak pôvodnej kompaktnej hrane dýky (obr. 2: 6) boli registrované na jedenástich artefaktoch (A 254 931, A 360 187, A 360 215, A 360 318, A 360 321, V 1047, V 5710, V 8099, SMR 26, SMR 2506, K 67). Podobne ako pri predchádzajúcej plastickej deformácii nemožno vylúčit vznik niekol'kých opakovaných zárezov na jednej hrane čepele. Súbory zásekov prejavujúcich sa ako zvlnenie čepele (obr. 3: 1) boli identifikované len na troch dýkach (A 360321 , V 8099, SMR 2506). Pôvod tejto „retuše“ je spojovaný so sklzom hrany na čepeli po druhej čepeli.

Rôzne druhy prasklín boli pozorované na väčšine dýk (A 254 931, A 360 187, A 360 215, A 360 318, A 360 321, A 519 263, V 5710, V 8099, SMR 26, K 67). Vznikajú v oslabených miestach artefaktu priamo po náraze alebo údere (obr. 2: 5). K popraskaniu artefaktu môže dôjst' i vplyvom neskorších podmienok - napr. hrobovým závalom (obr. 3: 2-3).

\section{Rezíduá}

Ako už bolo spomenuté vyššie, výsledkom observácie bola i identifikácia prevažne organických rezíduí, ale zatial' bez špecifikácie konkrétneho druhu materiálu. Pozostatky drevenej rukoväte (obr. 2: 2, 3) boli identifikované na troch čepeliach (A 360 215, SMR 3, SMR 26). V prípade dýky SMR 3 sa čast' dreva vyskytovala i na samotnej čepeli a nielen v okolí rukoväte. V tomto štádiu je asi možné vziat v úvahu skutočnost', že dýka bola uložená v celodrevenom obale. Odtlačky organického materiálu mal priamo na čepeli i artefakt A 360215 . V tomto prípade ale už nemožno definitívne potvrdit', či ide o organický obal čepele alebo len o odtlačok organického materiálu v mieste uloženia (napr. koreňový systém v hrobovom kontexte). Na tyle čepele SMR 26 bola na nezačistenej ploche kovu pozorovaná i živica, ktorá pravdepodobne slúžila na spevnenie úchytu rukoväti čepele (obr. 3: 4).

\section{DISKUSIA A OTÁZKA ĎALŠÍCH PERSPEKTÍV}

Výsledky analýzy pracovných stôp na artefaktoch (tabela 2) ukazujú, že súbor 15 dýk zo stredočeských pohrebísk je vhodným reprezentantom $\mathrm{k}$ formulovaniu predbežných záverov. Pracovné stopy $\mathrm{v}$ podobe plastických deformácií alebo makroskopicky pozorovaných zmien sa objavili na všetkých čepeliach dýk, niekedy samostatne (obr. 2: 3; 2: 6), inokedy $\mathrm{v}$ kombinácii viacerých markantov (obr. 2: 4, 5). Identifikácia rezíduí (obr. 2: 3; 3: 3, 4) poukazuje na spôsoby upevnenia rukoväti a uloženie v organických obaloch.

V súvislosti s týmto zistením možno formulovat zatial' len prvotné hypotézy, ktoré by naznačovali, že dýky ukladané do hrobov neboli len artefaktmi špeciálne vyrobenými pre potreby pohrebného rítu (cf. Neustupný 1997). Ukazuje sa skôr možnost', že pred deponovaním boli používané $\mathrm{v}$ bežnom živote, či už ako nástroje alebo zbrane. Zároveň tento predpoklad nevylučuje ich symbolickú úlohu, či už počas rituálnych aktivít za života alebo v následnom pohrebnom kontexte (cf. Petriščáková 2019).

Pre vyslovenie konkrétnejších hypotéz je nutné získat väčší počet dát a zamerat sa na celkovú analýzu artefaktov, vrátane metalurgického/výrobného a povýrobného procesu a zahrnút i experimentálnu fázu, ktorá by pomohla rekonštruovat 
Tabela 2. Výsledky analýzy pracovných stôp na kovových čepeliach dýk z pohrebísk staršej doby bronzovej v Čechách. $\mathrm{x}=$ pozitívne zistenie.

\begin{tabular}{|c|c|c|c|c|c|c|c|c|c|c|c|}
\hline \multirow[b]{2}{*}{ 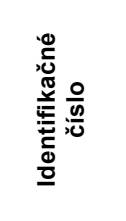 } & \multicolumn{8}{|c|}{ Pracovné stopy } & \multicolumn{3}{|c|}{ Postdepozičné zmeny } \\
\hline & 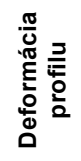 & 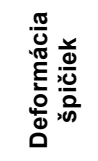 & 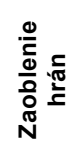 & 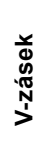 & & 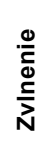 & 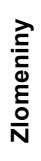 & 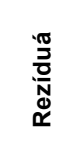 & 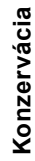 & 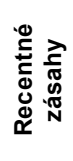 & 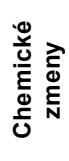 \\
\hline A 254931 & - & - & - & $x$ & $x$ & - & $\mathrm{x}$ & - & $\mathrm{x}$ & $x$ & - \\
\hline A 360187 & - & $\mathrm{x}$ & - & $\mathrm{x}$ & $x$ & - & $\mathrm{x}$ & - & $\mathrm{x}$ & $x$ & - \\
\hline A 360215 & $x$ & $\mathrm{x}$ & $\mathrm{x}$ & $\mathrm{x}$ & $\mathrm{x}$ & - & $x$ & drevo & $\mathrm{x}$ & $x$ & - \\
\hline A 360318 & - & $\mathrm{x}$ & $\mathrm{x}$ & - & $x$ & - & $\mathrm{x}$ & - & $\mathrm{x}$ & $\mathrm{x}$ & $x$ \\
\hline А 360321 & - & - & - & - & $\mathrm{x}$ & $\mathrm{x}$ & $\mathrm{x}$ & - & $\mathrm{x}$ & $x$ & $x$ \\
\hline A 360326 & $x$ & $x$ & - & - & - & - & - & - & $\mathrm{x}$ & $x$ & $x$ \\
\hline A 519263 & - & - & - & $x$ & - & - & $x$ & - & $\mathrm{x}$ & $x$ & $x$ \\
\hline V 1047 & - & - & $x$ & - & $x$ & - & - & - & $\mathrm{x}$ & $x$ & - \\
\hline V 4400 & - & - & $x$ & $x$ & - & - & - & - & $\mathrm{x}$ & $x$ & - \\
\hline V 5710 & - & $\begin{array}{l}\text { opra- } \\
\text { covaná } \\
\text { špička }\end{array}$ & $x$ & - & $\mathrm{x}$ & - & $\mathrm{x}$ & - & $\mathrm{x}$ & $x$ & - \\
\hline V 8099 & - & $x$ & $x$ & $x$ & $x$ & $\mathrm{x}$ & $\mathrm{x}$ & - & $\mathrm{x}$ & $\mathrm{x}$ & - \\
\hline SMR 3 & - & $x$ & - & - & - & - & - & drevo & - & $x$ & - \\
\hline SMR 26 & - & $x$ & - & - & $x$ & - & $\mathrm{x}$ & $\begin{array}{l}\text { drevo, } \\
\text { živica }\end{array}$ & - & $\mathrm{x}$ & $\mathrm{x}$ \\
\hline SMR 2506 & - & $\begin{array}{l}\text { opra- } \\
\text { covaná } \\
\text { špička }\end{array}$ & - & - & $\mathrm{x}$ & $\mathrm{x}$ & - & - & $\mathrm{x}$ & $\mathrm{x}$ & - \\
\hline K 67 & - & $\begin{array}{c}\text { opra- } \\
\text { covaná } \\
\text { špička }\end{array}$ & - & $x$ & $x$ & - & $x$ & - & $x$ & $x$ & - \\
\hline
\end{tabular}

celkový systematický kontext tzv. „životný cyklus artefaktov" (Gosden/Marshall 1999; Molloy 2011; Sych 2015). V neposlednom rade je nutné postulovat dalšie kategórie vplyvov, ktoré postihujú artefakty v postdepozičnom procese z hladiska ich nálezového kontextu (Horn/von Holstein 2017).V rámci prevádzania analýzy je vhodné zamerat' sa aj na recentné praktiky v spôsobe konzervácie a ošetrenia predmetov, ktoré môžu mat' negatívny dopad pre dosiahnutie optimálnych podmienok pre analýzu pracovných stôp na kovových artefaktoch (Bunnefeld/Schwenzer 2011; Dolfini 2011).

V aktuálnom stave vytvára absencia experimentálnych pokusov na replikách dýk s presne špecifi- kovaným prvkovým zložením suroviny a analýza pracovných stôp na základe fotografickej dokumentácie určité limity v pozorovaní, takže vznik pracovných stôp nie je možné presnejšie definovat'. Zároveň je vhodné uvedomit si, že väčšina porovnávaných stôp pochádza z predmetov iného morfologického tvaru a vel'kosti (meče, oštepy, Stabdolchy, sekery). Z typologického i funkčného hladiska je predpokladaný odlišný spôsob používania týchto artefaktov. Na druhej strane sa ponúka úvaha, že určité pracovné stopy pozorované makroskopicky i mikroskopicky vznikali na artefaktoch s čepelou rôznych tvarov a dížok analogickým spôsobom. 


\section{LITERATÚRA}

Bartelheim 1998 - M. Bartelheim: Studien zur bömischen Aunjetitzer Kultur: Chronologische und Chorologische Untersuchungen. UPA 46. Bonn 1998.

Bunnefeld/Schwenzer 2011 - J.-H. Bunnefeld/S. Schwenzer: Traditionen, Innovationen und Technologietransfer - zur Herstellungstechnik und Funktion älterbronzezeitlicher Schwerter in Niedersachsen. Prähistorische Zeitschrift 86, 2011, 207-253.

Daněček 2016 -D. Daněček: Hostivice, okr. Praha-západ, lok. 420. Výzkumy v Čechách 2011-2012, 2016, 103.

Daněček/Klementová 2014 - D. Daněček/J. Klementová: Holubice, okr. Praha-západ. Středočeský vlastivědný sborník 32, 2014, 94-96.

Daněček/Kvěchová/Vávrová 2015 - D. Daněček/E. Kvěchová/B. Vávrová: Holubice, okr. Praha-západ. Středočeský vlastivědný sborník 33, 2015, 118-121.

Dobisíková/Hložek/Menšík 2018 - M. Dobisíková/J. Hložek/ J. Menšík: Několik poznámek k možnostem interpretace hrobu únětické kultury z Holubic, okr. Prahazápad. Acta Musei Nationalis Pragae. Historia 72/1-2, 2018, 29-36.

Dolfini 2011 - A. Dolfini: The function of Chalcolithic metalwork in Italy: an assessment based on use-wear analysis. Journal of Archaeological Science 38, 2011, 1037-1049.

Dolfini/Crellin 2016 - A. Dolfini/R. J. Crellin: Metalwork wear analysis: The loss of innocence. Journal of Archaeological Science 66, 2016, 78-87.

Dolfini a i. ed. 2018 - A. Dolfini/R. J. Crellin/C. Horn/ M. Uckelmann (eds.): Prehistoric Warfare and Violence. Quantitative and Qualitative Approaches. Cham 2018.

Ernée ed. 2015-M. Ernée (ed.): Prag-Miškovice. Archäologische und naturwissenschaftliche Untersuchungen zu Grabbau, Bestattungssitten und Inventaren einer frühbronzezeitlichen Nekropole. RGF 72. Darmstadt 2015.

Ernée/Profantová a i. 2011 - M. Ernée/N. Profantová/ H. Březinová/J. Frána/A. Majer/P. Stránská: Pohřebiště únětické kultury v Klecanech, okr. Praha-východ. Archeologické rozhledy 63, 2011, 307-330.

Gosden/Marshall 1999 - C. Gosden/Y. Marshall: The Cultural Biography of Objects. World Archaeology 31, 1999, 169-178.

Gutierrez-Sáez/Martín-Lerma 2015 - C. Gutierrez-Sáez/ I. Martín-Lerma: Traceology on metal. Use-wear marks on copper-based tools and weapons. In: J. Marreiros/J. F. Gibaja Bao/N. Bicho (eds.): Use-wear and Residue Analysis in Archaeology. New York 2015, 171-188.

Horn 2013a - C. Horn: Weapons, fighters and combat: spear and swords in Early Bronze Age. Danish Journal of Archaeology 2/1, 2013 20-44.

Horn $2013 b$ - C. Horn: Harm's way. An approach to change and continuity in prehistoric combat. Current Swedish Archaeology 21, 2013, 93-116.

Horn 2017 - C. Horn: Combat and ritual - Wear analysis on metal halberds from the Danish Isles and the Cimbrian Peninsula. Journal of Archaeological Science 14, 2017, 515-529.

Horn 2018 - C. Horn: Die by the sword ... or the spear? Early bronze weapons in Scandinavia. In: M. Fernández-Götz/N. Roymans (eds.): Conflict Archaeology. Materialities of Collective Violence from Prehistory to Late Antiquity. London - New York 2018, 51-60.
Horn/Karck 2019 - C. Horn/T. Karck: Weapon and tool during the Nordic Bronze Age. Danish Journal of Archaeology 8, 2019, 1-20.

Horn/von Holstein 2017 - C. Horn/I. C. C. von Holstein: Dents in our confidence: The interaction of damage and material properties in interpreting use-wear on copper-alloy weaponry. Journal of Archaeological Science 81, 2017, 90-100.

Jiráň ed. 2008 - L. Jiráň (ed.): Archeologie pravěkých Čech 5. Doba bronzová. Praha 2008.

Jiráň ed. 2013 - L. Jiráň (ed.): The Prehistory of Bohemia 4. The Bronze Age. Prague 2013.

Keates 2002 -S. Keates: The flashing blade: copper, colour and luminosity in north Italian Copper Age society. In: A. Jones/G. MacGregor (eds.): Colouring the Past: The Significance of Colour in Archaeological Research. Oxford 2002, 109-126.

Kristiansen 2002 - K. Kristiansen: The tale of the swords: swords and swordfighters in Bronze Age Europe. $O x$ ford Journal of Archaeology 21/4, 2002, 319-332.

Limburský a kol. 2018 - P. Limburský a kol.: Pohřební areály únětické kultury ve Vliněvsi. Praha 2018.

Melheim/Horn 2014 - L. Melheim/Ch. Horn: Tales of hoards and swordfighters in Early Bronze Age Scandinavia: The brand new and the broken. Norwegian Archaeology Review 47, 2014, 18-41.

Molloy 2008 - B. Molloy: Martial arts and materiality: a combat archaeology perspective on Aegean swords of the fifteenth and fourteenth centuries BC. World Archaeology 40/1, 2008, 116-134.

Molloy 2011 - B. Molloy: Use-wear analysis and use-patterns of Bronze Age sword. In: M. Uckelmann/M. Mödlinger (eds.): Bronze Age Warfare: Manufacture and Use of Weaponry. BAR 2255. Oxford 2011, 67-84.

Molloy 2017 - B. P. C. Molloy: Hunting warriors: The transformation of weapons, combat practices and society during the Bronze Age in Ireland. European Journal of Archaeology 20/2, 2017, 1-37.

Moucha 1954 - V. Moucha: Rozbor únětického pohřebiště v Polepech u Kolína. Archaeologické rozhledy 6, 1954, 502-503, 523-536, 566-567, 573-575.

Mödlinger 2011 - M. Mödlinger: Ritual object or powerful weapon - the usage of central Europe Bronze Age swords. In: M. Uckelman/M. Mödlinger (eds.): Bronze Age Warfare: Manufacture and Use of Weaponry. BAR 2255. Oxford 2011, 143-166.

Needham/Bray 2015 - S. P. Needham/P. Bray: Daggers and knives. In: A. Woodwoord/J. Hunter (eds.): Ritual in Early Bronze Age Grave Goods. An Examination of Ritual and Dress Equipment from Chalcolitic and Early Bronze Age Graves in England. Oxford - Philadelphia 2015, 24-58.

Neustupný 1997 - E. Neustupný: Šňůrová sídliště, kulturní normy a symboly. Archeologické rozhledy 49, 1997, 304-322.

Novák 2011 - P. Novák: Die Dolche in Tschechien. PBF VI/13. Stuttgart 2011.

O'Flaherty/Gilchrist/Cowie 2011 - R. O'Flaherty/M. D. Gilchrist/T. Cowie: Ceremonial or deadly serious? New insight into the function of Irish Early Bronze Age halberts. In: M. Uckelmann/M. Mödlinger (eds.): Warfare in Bronze Age Europe: Manufacture and Use of Weaponry. BAR 2255. Oxford 2011, 39-52. 
Perucchetti/Northover/David-Elbiali 2020 - L. Perucchetti/J. P. Northover/M. David-Elbiali: What is a dagger? A metallurgical interpretation of three metal daggers from western Switzerland dated from the Late Neolithic to the Early Bronze Age. Journal of Archaeological Science. Reports 30/102251, 2020 [online]. https://doi.org/10.1016/j. jasrep.2020.102251 [31-05-2020].

Peška/Králík/Selucká 2006 - J. Peška/M. Králík/A. Selucká: Rezidua a otisky organických látek v korozních produktech mědi a jejich slitin. Pilotní studie. Industrie starší doby bronzové. Památky archeologické 97, 2006, 5-46.

Petriščáková 2009 - K. Petriščáková: Pohrebiská v Stodůlkach, Jinoniciach a Butoviciach a ich výpoved'o myslení a obyčajoch komunity únětickej kultúry v mikroregióne Prahy 5. Bakalárska práca. Filozofická Fakulta Univerzity Karlovy. Praha 2009. Nepublikované.

Petriščáková 2014 - K. Petriščáková: Únětické hroby v Praze 13-Stodůlkách. Archaeologica Pragensia 22, 2014, 652-670.

Petriščáková 2019 - K. Petriščáková: Symbolika hrobov so zbran̆ami na konci eneolitu a na začiatku staršej doby bronzovej na území Čiech. Dizertačná práca. Filozofická Fakulta Univerzity Karlovy. Praha 2019. Nepublikované.

Skak-Nielsen 2009 - N. V. Skak-Nielsen: Flint and metal daggers in Scandinavia and other parts of Europe: A re-interpretation of their function in the Late Neo-

Rukopis prijatý 14. 6. 2020

Translated by Peter Pavúk and Judd Burden

PhDr. Katarína Petriščáková, Ph.D.

Muzeum hlavního města Prahy

Kožná 1

CZ - 11001 Praha 1

petriscakova@muzeumprahy.cz

Dr. Marek Verčík

Ústav pro klasickou archeologii

Filozofická fakulta Univerzity Karlovy

Nám. Jana Palacha 2

CZ - 11638 Praha 1

marek.vercik@ff.cuni.cz

doc. PhDr. Peter Pavúk, Ph.D.

Ústav pro klasickou archeologii

Filozofická fakulta Univerzity Karlovy

Nám. Jana Palacha 2

CZ - 11638 Praha 1

peter.pavuk@ff.cuni.cz lithic and Early Copper and Early Bronze. Antiquity 83, 2009, 349-358.

Smejtek 2005 - L. Smejtek: Praha bronzová. In: M. Lutovský /L. Smejtek a kol.: Pravěká Praha. Praha 2005, 349-590.

Soriano-Llopis/Gutierrez-Sáez 2008 - I. Soriano-Llopis/

C. Gutierrez-Sáez: Use-Wear Analysis on Metal: The Influence of Raw Material and Metallurgical Production Processes. In: $2^{\text {nd }}$ International Conference Archaeometallurgy in 2007. Selected papers. 17-21 June 2007, Aquileia - Italy. Milano 2008, 1-11.

Sych 2015 - D. Sych: Cultural biographies of bronze knives and sickles from South-West Poland. Ślaskie sprawozdania archeologiczne 57, 2015, 115-127.

Šulová 2013 - L. Šulová: Únětické hroby ze Svrkyně, okr. Praha-západ. Archeologie ve středních Čechách 17, 2013, 515-526.

Uckelmann 2011 - M. Uckelmann: The function of Bronze Age shields. In: M. Uckelmann/M. Mödlinger (eds.): Bronze Age Warfare: Manufacture and Use of Weaponry. BAR 2255. Oxford 2011, 187-199.

Wall 1987 - J. Wall: The role of daggers in Early Bronze Age Britain: the evidence of wear analysis. Oxford Journal of Archaeology 61, 1987, 115-118.

Weinberger 2008 - S. Weinberger: Warfare in the Austrian Weinviertel during the Early Bronze Age. Wien 2008.

PhDr. Mgr. Petr Limburský, Ph.D.

Archeologický ústav AV ČR, Praha, v.v.i.

Letenská 4

CZ - 11800 Praha 1

limbursky@arup.cas.cz

Mgr. David Daněček

Archeologický ústav AV ČR, Praha, v.v.i.

Letenská 4

11800 Praha 1

Středočeské muzeum v Roztokách u Prahy

Zámek 1

CZ - 25263 Roztoky

danecek@muzeum-roztoky.cz

Mgr. Michal Ernée, Ph.D., DSc.

Archeologický ústav AV ČR, Praha, v.v.i.

Letenská 4

CZ - 11800 Praha 1

ernee@arup.cas.cz 


\title{
From Tools and Weapons to Symbols: Use-wear Analysis of the Early Bronze Age Metal Daggers in Bohemia

\author{
Pilot Study
}

\author{
Katarína Petriščáková - Marek Verčík - Peter Pavúk - \\ Petr Limburský - David Daněček - Michal Ernée
}

SUMMARY

One of the typical traits of the Early Bronze Age material culture is the use of daggers in the burial rite. While the more descriptive aspects of their analysis are already rather settled, an understanding of their social context, the reflection of which is often additionally skewed by the post-depositional processes, is still an open issue. The local daggers have so far been tackled largely along the lines of their general presence or absence in the graves, their typology and the resulting chronology (Bartelheim 1998; Ernée ed. 2015; Jiráň ed. 2008; Limburský a kol. 2018; Novák 2011; Smejtek 2005 etc.). The function of daggers, and their importance in a social context, have rather been neglected. However, research abroad identified methodological procedures for the analysis of use-wear traces, which greatly enlighten the original use of the metal finds (e.g. Dolfini/Crellin 2016; Gutiérrez-Sáez/Martín-Lerma 2015; Horn 2013a; 2013b; 2017; Horn/von Holstein 2013; Melheim/Horn 2014; Molloy 2017; Mödlinger 2011 etc.). While the said studies target typologically different artefacts, associated strictly with the military phenomena, the approach can also be very well applied to our material (cf. Petriščáková 2019).

This pilot study therefore focuses on the analysis of usewear traces on 15 metal daggers from six burial grounds of the Únětice culture in Central Bohemia (Fig. 1). The preserved length of the blades and the number of rivet-holes vary considerably, reflecting thus a broader typology. All the examined pieces come from inhumation graves (Table 1). The functional analysis focused on traces of use, the impact

Fig. 1. Early Bronze Age burial grounds with daggers in Bohemia. 1 - Prague-Jinonice; 2 - Prague-Stodůlky; 3 - Vliněves, district Mělník; 4 - Holubice, Prague-West; 5 - Hostivice, Prague-West; 6 - Klecany, Prague-East (graphic design by M. Kafka).

Fig. 2. Use-wear traces on metal blades of daggers from the Early Bronze Age burial grounds in Bohemia. 1 - dagger A 360326, torsion; 2-dagger SMR3, before lab treatment, broken tip with chalky sinter and wooden remains on the butt; 3 - dagger V 5710, damage of blade tip; 4 - dagger 360215 , V-shaped nick (above) and rounding (below); 5-dagger V 8099, V-shaped nick with fissure; 6 - dagger A 360 187, U-shaped notch (microscopic imaging by K. Petriščáková; graphic design by M. Kafka).

Fig. 3. Use-wear traces on metal blades of daggers from the Early Bronze Age burial grounds in Bohemia. 1 - dagger SMR 2506, rippling; 2 - dagger A 360 215, almost invi- of post-depositional processes and the evidence of eventual residues (Table 2). Macroscopic observation focused on physical deformations, such as various asymmetries and broken parts (torsion, deformation, damage of the blade tips, rounding, and fissures). Plastic deformations (such as nicks, notches, and rippling) were observed microscopically. These traces indicate the endurance of the material, its ability to deform against the applied force, but also the inability to return to the original state. Interestingly, the various use-wear traces on the dagger blades commonly appeared in combination. The identification of diverse residues was more of a bonus and made it possible to study the manufacture, design and storage possibilities for the daggers.

So far, only general hypotheses can be formulated, the main one being that the daggers placed in graves were not just symbolic artefacts made specially for the rites linked with the funeral. Rather, there is a good possibility that they were used in everyday life before deposition, either as tools or weapons. At the same time, this assumption does not exclude their symbolic role in the subsequent funeral context (cf. Neustupný 1997).

To make more specific claims, it is necessary to obtain more data and focus on a more holistic analysis of the artefacts, including the metallurgical/manufacturing and post-production processes, and to initiate an experimental phase that would help reconstruct the overall systematic context, the so-called 'life cycle of the artefacts' (Molloy 2011; Sych 2015).

sible blade fissures and wooden remains on the butt; 3 - dagger A 360 215, X-Ray of fissures; 4 - dagger SMR 26, natural resin on blade butt; 5 - dagger V 4400, blade after lab treatment (imitation of varnishing); 6- dagger A 230 102, blade after lab treatment (scratching surface); 7 -dagger SMR 3, recent incision (microscopic imaging by K. Petriščáková; graphic design by M. Kafka).

Table 1. Daggers from the Early Bronze Age burial grounds in Bohemia. Material and context. Abbreviations: MMP - The City of Prague Museum; ARÚP - Institute of Archaeology of the Czech Academy of Sciences, Prague, v. v. i.; SMR - Central Bohemian Museum in Roztoky by Prague.

Table 2. The results of use-wear analysis on the metal blades of daggers from the Early Bronze Age burial grounds in Bohemia. $x=$ positive find/affirmation . 
